\title{
MANAJEMEN PONDOKPESANTREN DALAM PENDIDIKAN MORAL MASYARAKAT (Studi Kasus di Pesantren Radhatul Ulum Sakatiga)
}

\author{
Suhaila \\ Badan Pengembangan Sumber Daya Manusia \\ Email : suhaila_aja@yahoo.com
}

\begin{abstract}
ABSTRAK
Penelitian ini mendeskripsikan manajemen pondok pesantren dalam pendidikan moral masyarakat yang fokus kajiannya adalah di pondok pesantren Raudiatul Muta'allimin di Lingkungan Masyarakat Desa Sakatiga. Tujuannya adalah untuk mengetahui: pertama, jenis nilai-nilai moral yang diajarkan pesantren Raudiatul Muta'allim di Lingkungan Desa Seda Rembang, Ketiga, bentuk penanaman moral pesantren Raudhatul Ulum di lingkungan desa Sedang Rembang, Keempat, hambatan penanaman moral pesantren Raudiatull Muta'allim di lingkungan desa Sedan Rembang, kelima, evaluasi dan upaya mengatasi hambatan pesantren Raudhatul Ulumdi lingkungan desa Sedan Rembang. Sedangkan hasil dari penelitian jni adalah : 1) Terdapat dua nilai moral yang diiajarkan pesantren Raudhatul Ulum, yaitu moral agama dan sosial, nilai sosial, 2) Teknik penanaman moral tersebut dengan berinterajsi secara langsung dengan masyarakat di lingkungan desa Sedan Rembang, 3) Pendidikan moral pesantren Raudhatul Ulum dengan cara menyelenggarakan pengajian baik umum maupun khusus, dan melakukan berbagai kegiatan sosial, 4) Hambatannya adalah kurang adanya singkronisasi jadwal kegiatan dengan jam-ja kerja secara rutin di lingkungan masyarakat, dan 5) evaluasi dan upaya mengatasi hambatan adalah melakukan pendekatan secara intens kepada warga masyarakat di lingkungan sekitar pesantren dengan cara melakukan perubahan jadwal kegiatan dengan hari-hari libur kerja, kemudian tersosialisasi secara baik.
\end{abstract}

Kata Kunci : Manajemen Pondok Pesantren, Pendidikan Moral, Masyarakat.

\section{PENDAHULUAN}

Seiring dengan perkembangan zaman, pondok pesantren tetap eksis sebagai lembaga pendidikan Islam. Pendidikan agama di pesantren bertujuan untuk meningkatkan moral para santri dengan metode penyucian diri (tazkiyatun nafs) dan latihan spritual (riyadah ruhiyyah).

Mayoritas keberadaan pesantren didirikan oleh komunitas masyarakat setempat, sebagai perwujudan dari, oleh, dan untuk masyarakat. Pesantren bertujuan untuk mempersiapkan generasi muda muslim dengan pendidikan agama yan lebih baik dan membekali mereka komitmen terhadap ajaran-ajaran Islam. Pesantren merefleksikan kolektifitas kehidupan dan spirit masyarakat di lingkungan pedesaan.Berdirinya pesantren tidak bisa dipisahkan dari nilai keagamaan, baiknya kerjasama nilai keagamaan, baiknya kerjasama (ta'awan), kepatuhan, kesederhanaan, independensi dan keikhlasan. Dari sini bisa dikatakan bahwa pesantren merupakan pendidikan yang berbasis komunitas masyarakat di lingkungan pedesaan.

Moral merupaan sebuah ukuran baik dan buruk yang diakui oleh komunitas masyarakat atau kelompok tertentu yang menyepakatinya baik didasarkan pada agama maupun tidak. Moral memiliki peranan sebagai pembentuk pribadi umat manusia yang berakhlakul karimah sevara utuh dalam menghadapi berbagai problem kehidupan. Dalam kehidupan bermasyarakat, eksistensi moral penting untuk dibutuhkan sebagai pondasi perilaku agar terwujud suatu keadaan yang kondusif dan harmonisasi antar umat manusia. Moral atau 
perilaku yang baik dari seseorang biasanya timbul akibat dari faktor luar dan dalam. Adapun yang dari faktor luar, keberadaan moral seseorang bisa terbentuk dari lingkungan keluarga, sekolah/madrasah dan masyarakat. Dalam lingkungan masyarakat, terdapat lembaga pendidikan yang berupaya membentuk perilaku yang baik atau moral seseorang salah satu lembaga itu adalah pondok pesantren. Karena pendidikan pesantren, khususnya pendidikan agama bertujuan untuk meningkatkan moral para santri dengan metode-metode khusus, salah satunya adalah tazkiyatun nafs dan riyddah nihiyyah.

Sebagaimana yang diungkapkan KH. Said Aqil Siroj (2012:44) bahwa kehadiran agama telah memberikan petunjuk praktis dalam kerangka penyempumaan moralitas manusia. Dalam diri manusia terkandung potensi berbuat baik dan buruk. Agama tidak menyangkal bahwa manusia dengan akalnya sudah mampu membedakan antar yang baik (al-haq) dan yang buruk (al-bdtil). Namun, agama juga melegitimasi bahwa kekuatan akal manusia tidak akan mampu menangkap hakikatmanusia.

Pondok pesantren Raudlotul Muta'allimin adalah sebuah lembaga pendidikan agama islam yang didirikan oleh para ulama, sesepuh dan tokoh masyarakat di wilayah desa Sedan Kecamatan Sedan Kabupaten Rembang. Keberadaan pondok pesantren Raudlotul Muta'allimin sangat dibutuhkan oleh masyarakat dan ia selalu berintegrasu dengan lingkungan masyarakat. Karena keberadaan pesantren didirikan oleh komunitas masyarakat setempat, sebagai perwujudan dari oleh, dan untuk masyarakat.

Oleh karena itu, peneliti berkeinginan untuk memaparkan tema sentral yaitu Manajemen Pondok Pesantren dalam Pendidikan Moral Masyarakat yang di fokuskan pada Studi Kasus di Pesantren Raudhatul Ullum di Lingkungan Masyarakat Desa Sakatiga

\section{METODE PENELITIAN}

Penelitian ini menggunakan pendekatan kualitatif deskriptif. Penelitian kualitatif munurut Bogdan dan Biklen (1982:21) memiliki karakteristik tersendiri yaitu : dilaksanakan pada latar yang alamiah, menggunakan manusia sebagai instrument utama, lebih memperhatikan proses dari pada hasil. Pendekatan kualitatif mencoba menjelaskan dan menggambarkan tentang adanya peran pondok pesantren Raudhatul Ullum dalam pendidikan moral masyarakat di lingkungan desa Sakatiga. Secara interaktif, peneliti mengumpulkan data-data dan melakukan wawancara mengenai obyek penelitian hubungannya dengan peran pendidikan moral di lingkungan desa Sedan Rembang.

Menurut Bogdan dan Taylor sebagaimana dikutip Moleong (2015:4) mengatakan bahwa kualitatif merupakan cara dan prosedur penelitian yang menghasilkan data deskriptif, berupa katakata tertulis atau lisan dari orang-orang serta perilaku yang dapat diamati. Sedangkan Krik dan Milter sebagaimana dikutip Meolong (2005:4) juga mendefinisikan bahwa penelitian kualitatif adalah tradisi tertentu dalam ilmu pengetahuan ilmu sosial yang secara fundamental bergantung dalam kawasannya maupun dalam peristilahannya. Dengan menggunakan metode penelitian kualitatif, peneliti memiliki kebebasan dalam memilih data dan menggunakan metode pengolahan data,

Pendekatan kualitatif juga berusaha mengumpulkan data deskriftif yabg sebanyakbanyaknya, kemudian dituangkan dalam bentuk beberapa laporan atau uraian yang diperoleh dari catatan lapangan, dokumen, karya-karya ilmiah dan lain-lain. Kemudian data tersebut dianalisa secara intem dan terus menenus dari awal sampai akhir penelitian dan bergerak secara induktif, termasuk juga melalui sintesis dan mengembangkan teori. Pendekatan kualitatif sering digunakan dalam penelitian, karena bersifat umum dan fleksibel dalam mengkaji masalah manusia, kebudayaan, dan moral (Meolong, 2002:23).

Ada beberapa pertimbangan dalam penelitian ini penulis menggunakan metode kualitatif, antara lain : pertama, menyesuaikan metode ini itu lebih mudah bila berhadapan dengan kenyataan yang ada. Kedua, metode ini menyajikan hakikat hubungan antara peneliti dengan informan secara langsung. Ketiga, metode ini lebih peka dan lebih dapat menyesuaikan diri dengan banyak penajaman pengaruh bersama dan pola-pola nilai yang dihadapi.

Jenis peneliti yang digunakan dalam karya ilmiah ini adalah studi kasus yan merupakan inkuiri empiris yang menyelidiki fenomena dalam konteks kehidupan nyata, bilamana batas-batas antara fenomena dan konteks tidak tampak dengan tegas dan dimana-dimana multi sumber bukti dimanfaatkan.

Rancangan yang digunakan dalam penelitian ini, ialah rancangan studi kasus, karena studi kasus 
lebih menekankan pada pengungkapan secara rinci dan mendalam terhadap suatu obyek, peristiwa yang ada. Penelitian ini di fokuskan untuk mengungkapkan suatu peristiwa dan kegiatan yang ada hubungannya dengan pondok pesantren Raudlotul Muta'llimin di lingkungan masyarakat, maka penelitian ini menggunakan studi kasus observasional.

\section{Hasi dan Pembahasan}

\section{Pendidikan Nilai Moral Pondok Pesantren Raudhatul Ulum di Lingkungan Masyarakat}

Manajemen pondok pesantren

Raudhatul Ulum dalam pendidikan moral di lingkungan masyarakat desa Sedan Rembang menunjukkan bahwa pondok pesantren Raudhatul Ulum merencanakan dan mengajarkan nilai-nilai moral keagamaan bagi lingkungan masyarakat desa Sakatiga. Karena keberadaan pondok pesantren salah satunya bertujuan untuk mempersiapkan generasi muda Islam dengan pendidikan agama yang lebih baik membekali mereka komitmen terhadap ajaran-ajaran Islam. Nilai-nilai moral yang rencana untuk diajarkan di pondok pesantren Raudlotul Ulum tersebut antara lain : 1) tata cara beribadah kepada Allah SWT secara baik dan benar, sebagaimana yang ditegaskan dalam kajian kitab-kitab salaf yang diajarkan setiap selesai shalat maktubah, 2) pendidikan dan pengajarab taqarrub kepada Allah SWT dengan cara melakukan dzikirullah tiap minggu sekali secara berjam'ah, 3) saling gotong royong dan hormat-menghormati antar sesama manusia.

Untuk itu, pesantren dituntut untuk menjawab dan mengkontekstualisasikan diri dengan tanpa menghilangkan karakter dasar pendidikan dan jiwa pesantren itu sendiri. Pesantren sebagai sebuah lembaga yang berbasis sosial yang mempunyai rasa dan tanggung jawab terhadap perkembangan masyarakat sudah selayaknya memiliki kepedulian yang nyata untuk ikut serta dalam proses pembangunan bangsa, selain memajukan wawasan dan pengetahuan santri, pesantren juga berfungsi sebagai lembaga kemasyaratan yang mempunyai tugas-tugas sosial.

Dalam konteks ini, pesantren tidak hanya berfungsi sebagai lembaga pendidikan ansich, namun lebih dari itu, pesantren menjadi agen yang dinamis dan sebagai katalisator bagi masyarakat luas, tidak hanya dalam aspek keagamaan saja tetapi juga permasalahan ekonomi dan sosial yang menimpa masyarakat. Sehingga pesantren harus mampu membaca ulang khazanah kitab klasik untuk menghadapi tantangan zaman. Sebagai wujud pemenuhan tanggungjawab untuk menciptakan kemaslahatan umum (almaslahah al-ammah). Sejalan dengan pernyataan Kahfi (2003:39) bahwa pondok pesantren sangat berperan dalam lingkungan masyarakat, dengan adanya pondok pesantren maka masyarakat akan memiliki batasan dalam bertindak dan berpikir. Pondok pesantren dapat memberikan nilai moral terhadap masyarakat, karena pondok pesantren memiliki fungsi sebagai ilmu sosial dan ilmu akhlak bagi para santri-santri atau orang-orang yang berada di lingkungannya.

Disamping adanya pendidikan dan pengajaran nilai-nilai moral keagamaan, di pondok pesantren Raudhatul Ulum juga mengajarkan nilai moral sosial. Bentuk pengajaran nilai moral sosial itu antara lain: kerja bakti massal, khitanan massal, pendistribusian beras jumputan kepada masyarakat miskin, dan pengobatan massal. Hal ini sesuai dengan pemikiran KH. Sahal Mahfudh bahwa pesantren disamping sebagailembagakeagamaan, ia juga menupakan lembaga sosial kemasyarakatan yang dapat diharapkan membantu pemerintah dalam menyebarluaskan inovasi pembangunan kepada masyrakat, agar pesantren dan partisipasi mereka dapat dinvetarisir sedemikian rupa dan dimanfaatkan. Sebagai lembaga sosial, tugas yang digarap oleh pesantren bukan hanya soal-soal agama, melainkan juga pemasalahan-permasalahan sosial yang ada di sekitamya.

Dalam konteks seperti ini, pesantren diharapkan mampu membenahi lingkungan masyarakat yang pendidikan moralnya rendah, sehingga moral masyarakat yang ada di lingkungab pesantren banyak dipenganuhi oleh moral agam (Raharjo, 1985:18). Di lingkunganpedesaan, khususnya pesantren Raudhatul Ulum diharapkan bisa memberikan fungsi sosial bagi masyarakat yang berada di lingkungan nasyarakat sekitar. Para ulama san 
kyaipesantren, khususnya yang mengelola pesantren Raudhatul Ulum sangat dihormati oleh lingkungan masyarakat sekitar. Artinya, keberadaan pondok pesantren dengan lingkungan masyarakat merupakan hubungan yang harmonis, salin hormat menghormati, sehingga keberadaan lembaga pesantren menyatu dengan masyarakat. Sebagaimana pemikiran KH. Sahal Mahfudh bahwa pesantren memiliki ketertarikan yang sangat kuat dengan masyarakat sekitarnya. Pesantren, lazimnya didirikan atas dasar kebutuhan masyarakat setempat akan suatu instuisi pendidikan atau keagamaan.

2. Internalisasi Nilai-Nilai Moral di Lingkungan Masyarakat Desa Sakatiga

Hasil penelitian menujukkan bahwa cara menginternalisasikan nilai-nilai moral di lingkungan masyarakat desa Sakatiga salah satunya adalah berinteraksi secara langsung dengan masyarakat sekitar, karena letak pesantren tersebut berada di tengah-tengah lingkungan perkampungan warga masyarakat. Oleh karena itu, santri dapat dengan mudah berinteraksi, seperti membeli makanan/jajanan, alat tulis, dan semua jenis kebutuhan mereka sehari-hari.Kromo inggil (bahasa jawa yang halus) menupakan karakter santri dalam konteks bergaul dengan masyarakat di lingkungan sekitar pondok pesantren.Dengan keunggulan budi pekerti semacam itu, kemudian masyarakat merasa tertarik dan mau hadir dalam berbagai acara kegiatan yang diselenggarakan oleh pesantren Raudlotul Muta'llimin.Sebagaimana menguntip pendapat Rahardjo (1985:45) yang menyatakan bahwa santri adalah mereka yang memusatkan perhatiannya pada agama Islam, khususnya penafsiran moral sosialnya, mempunyai penekanan-penekanan yang berbeda.Santri mempunyai nilai dan watak tersendiri, yang secara ensensial lahir dari pemahaman agama, berkat nilai dan watak itulah mereka mampu memberikan suatu dimensi kehidupan yang submisif dan sertaibadah.

3. Penanaman

Moral

PondokPesantrenRaudhatulUlumdi Lingkungan Masyarakat Desa Sakatiga

Berbagai bentuk dan cara untuk menanamkan nilai-nilai moral yang diajarkannolehPondokPesantrenRaudhatulUlu msalahsatunyaadalahkegiatankeagamaansepert ipengajian, baiksecaraumum yang bisa diikuti oleh masyarakat secara menyelunuh yaitu di lingkungan desa Sedan Rembang, maupun pengajian khusus, setiap habis sholat berjama'ah. Model penanaman moral ada juga yang berbentuk kegiatan sosial, seperti kerja bakti massal, khitanan massal, pendistribusian beras jumputan kepada masyarakat miskin, dan pengobatan massal. Sehubungan dengan konteks ini, peneliti menguntip pemikiran Kahfi (2003:39) yang menyatakan bahwa peran pesantren dalam lingkungab sosial sangat besar dirasakan oleh masyarakat sebagai pengayom, tempat meminta tolong dan tempat pengaduan masyarakat. Masyarakat merupakan sekelompok manusia yang memiliki rasa kesadaran bersama di mana mereka berdiam pada daerah yang sama, yang sebagian besar atau seluruhwarganyamemperlihatkanadanyaadatke biasaandanaktivitas yang sama.Ada pula yang mendefinisikanbahwamasyarakatadalah sejumlah manusia yang meru-pakan satu kesatuan golongan yang berhubungan tetap dan mempunyai ke-pentingan yang sama. Seperti, sekolah, keluarga, perkumpulan, negara semua adalah masyarakat.

Berkenaan dengan hasil pene-litian, terkaitdenganbentukkegiatanpenanaman moral pondok pesantren Raudhatul Ulum di lingkungan masyarakat Desa Sakatiga wujudnya sangat beragam. Mereka memiliki moral bervariasi dalam menjalankan aktivitasnya. Pesantren bertekad untuk menanamkan nillai moral kepada masyarakat. Nilai ini memungkinkan manusia untuk mencapai kebahagiaan dirinya. Karena esensi moral adalah mengarahkan manusia untuk bertindak menuju kebaikan. Dan manusia adalah makhluk yang bebas untuk memilih dan mengolah segala potensi yang ia miliki, yang menjadikan berbeda dengan makhluk yang bebas untuk memilih dan mengolah segala potensi yang ia miliki, yang menjadikan berbeda dengan makhluk lain.

\section{Hambatan Penanaman Nilai Moral Pondok Pesantren Raudhatul Ulum di Lingkungan Masyarakat Desa Sakatiga}

Hambatan itu bentuknya ada dua, yaitu hambatan teknis dan non teknis. Berdasar hasil kajian di lapangan terkait dengan hambatan 
penanaman moral di Pondok Pesantren Raudlotul Muta'-allimin di lingkungan desa Sedan Rembang antara lain sebagai berikut:

1. HambatanteknisadalahadanyakegiatanPon dokPesantrenRaudhatulUlumyang diagendakanpadawaktupagi hari, kebetulan jam pagi hari bersamaan dengan jam-jam kerja lingkungan masyarakat sekitar pesantren. Dengan demikian warga lingkungan masyarakat tidak bisa mengikuti kegiatan yang diselengga-rakan oleh pesantren. Para pemuda dan remaja juga tidak bisa menghad-iri kegiatan pesantren, karena jam pagi hari mereka ratarata pergi sekolah.

2. Sedangkan hambatan non teknis, seperti adanya kurang maksimal dalam terselenggaranya acara dalam terselenggaranya acara kegiatan, kurang on time dalam berlangsung-nya acara kegiatan sehingga pelaks-anaannya molor, adanya kekurangan konsumsi, hadimya undangan yang sering membawa anak kecil sehingga menciptakan suasana kurang ny-aman.

Temuan penelitian diatas lalu dihubungkan dengan teori yang ada yaitu pendidikan yang terkait dengan moral tentu banyak masalah yang sering dihadapi oleh semua orang tua, guru dan masyarakat tanpa melihat latar belakang kehidupan sosialnya (Dar-ueso, 1989:22). Berkenaan dengan temuan hasil penelitian dan teori tersebut diatas bisa disimpulkan bahwa masih ada hambatan dalam menanam-kan nilai-nilai moral kepada masyarakat desa Sedan Rembang.

\section{Evaluasi dan Upaya Mengatasi Hambatan}

Salah satu evaluasi dan upaya yang dilakukan oleh pondok pesantren Raudhatul Ulum desa Sakatiga terkait dengan mengatasi kendala penanaman modal adalah melakukan pendekatan langsung kepada masyarakat untuk menarik perhatian mereka agar berkenan dan mau menghadiri berbagai kegiatan yang diprogramkan oleh pesentren. Kemudian warga masy-arakat juga melakukan upaya warga-warga di lingkungan mereka untuk hadir dalam acara kegiatan pesantren, baik acara keagamaan maupun kegiatan sosial yang lain. Pesantren juga melaku-kan perubahan jadwal kegiatan pada hari-hari libur, yang di sosialisasikan oleh pihak pondok pesantren kepada seluruh lingkungan masyarakat.

Setiap jenis hambatan tentu akan timbul seiring dengan perjalanan waktu dalam merealisasikan suatu program kegiatan, tetapi dari semua jenis hambatan yang ada tentu ada jalan keluarnya.

Dari uraian tersebut diatas bisa disimpulkan bahwa pesantren Raudhatul Muta'allimin dalam menerapkan manaj-emen pendidikan moral masyarakat khususnya yang ada di lingkungan desa Sakatiga, selalu akan memperbaiki berbagai kegiatan yang akan diberlakukan, sehingga proses manajemen pendidikan moral terhadap masyarakat di lingkungan desa Sedan Rembang bisa berjalan dengan optimal.

\section{Simpulan}

Deskripsi dalam penelitian yang memunculkan tema sentral yaitu Mana-jemen Pondok Pesantren dalam Pendidi-kan Moral Masyarakat yang di fokuskan pada Studi Kasus di Pesantren dalam Pendidikan Moral Masyarakat yang di fok-uskan pada Studi Kasus di Pesantren Raudlotul Muta'allimin di Lingkungan Masyarakat Desa Sedan Kabupaten Rembang dapat disimpulkan sebagai berikut:

1. Ada dua nilai moral yang diajarkan pesantren Raudlatul Muta'allimin, yaitu moral agama dan sosial.

2. Teknik penanaman moral tersebut dengan berinteraksi secara langsung dengan masyarakat di lingkungan desa Sedan Rembang

3. Pendidikan moral pesantren Raudlatul Muta'allimin dengan cara menyelengg-arakan pengajian baik umum maupun khusus, dan melakukan berbagai kegiatan sosial.

4. Hambatannya adalah kurang adanya singkronisasi jadwal kegiatan dengan jam-jam kerja secara rutin di lingk-ungan masyarakat

5. Evaluasi dan upaya mengatasi hambat-an adalah melakukan pendekatan secara intens kepada warga masyarakat di lingkungan sekitar pesantren

6. Melakukan perubahan jadwal kegiatan dengan hari-hari libur kerja, kemudian tersosialisasi secarabaik

\section{Daftar Pustaka:}


Aqil Siroj, Said, Tasawuf Sebagai Kritik Sosial, Jakarta:SAS Foundation, 2012

Bertens, K, Etika, Jakarta : Gramedia Pustaka Utama, 21

Bogdan, R, C \& Biklen, S. K. 1982, Quali-tative Research of Education: An Intro-duction to Theeory and Methods, London: Allyn and Bacon, Inc

Darueso, Bambang, Dasar dan Konsep Pendidikan Moral Pancasila, Semarang: Aneka Ilmu, 1989

Kahfi, Shohibul, Lentera Kehidupan dan Perjuangan Kiai Yahya, Lembaga Penerbit PondokPesatren(LP3MH), 2003

Mahfudh, Sahal, KH, Peran Ulama dan Pesantren dalam Upaya Peningkatan Derajat Kesehatan Umat, Makalah Saresehan di RS. Sultan Agung Semarang, 26 Agustus 2000

Moleong, Lexy J, Metodologi Penelitian Kualitatif (Edisi Revisi, Bandung: Remaja Rosdakarya, 2005)

Raharjo, Dawam, Pergulatan Dunia Pesa-ntren Membangun Dari Bawah, Jakarta :P3M, 1985

Raharjo, Dawam, Pesantren dan Pembah-aruan, Jakarta:LP3ES, 1988, Cet. IV

Syani, Abdul, 1995, Sosiologi dan Peruba-han Masyarakat, Bandar Lampung: Ou-staka Jaya

Usa, Muslih dan Wijaya, Aden, Pendidik-an Islam dalam Peradaban Industrial, Yogyakarta: Aditya Media, 1997

Zubaidi, Akhlak Tasawuf (Edisi Revisi), Yogyakarta: Lingkar M 